\title{
Circular Economy of Steel Recycling Companies in Thailand
}

\author{
Amirhossein Taghipour ${ }^{1} \cdot$ Wareerath Akkalatham ${ }^{2}$
}

Received: 25 April 2021 / Accepted: 5 May 2021 / Published online: 24 May 2021

(C) The Author(s), under exclusive licence to Springer Nature Switzerland AG 2021

\begin{abstract}
The new "circular economy" model would revolutionize the economy. It should also be noted that several business models will be needed to optimize their efficiency and overlap as the system evolves over its lifetime. The business model of the circular economy is based on the principle of "value creation" of the conventional economy. In this study, we interviewed 67 managers from the steel industry in Thailand. Statistically, $71.2 \%$ of respondents felt that steel consumers would be able to pay a higher price for clean goods. Also, $87 \%$ believe that governments must contribute to the development of the circular economy. They said that their group also organizes training activities for educating the workforce. Moreover, $80.1 \%$ indicated that their organization must inform management and workers of the value of the circular economy. Accordingly, $64.7 \%$ of respondents stated that there is no government funding for scrap metal recycling. Overall, $36.3 \%$ of people felt there was a shortage of scrap metal work.
\end{abstract}

Keyword Circular economy · Steel industry · Thailand · Stakeholders · Digital transformation

\section{Introduction}

Donati et al. [1] assumed that $28 \%$ of the material savings would be achieved by the use of steel and aluminum additives in the manufacture of transport components, precision instruments, and machinery and electrical equipment. In the absence of information on the potential penetration of competition, one believes that the whole production would benefit from the multiplication of the industrial revolution via using mechanical engineering [2]. On the other

Amirhossein Taghipour

Amirtg149@gmail.com

Wareerath Akkalatham

Wareerath.1403@gmail.com

1 King Mongkut's Institute of Technology Ladkrabang, Bangkok, Thailand

2 Kasetsart University, Bangkok, Thailand 
hand, the socio-economic indicators have slightly decreased while actions to minimize losses in yields often suggest some environmental benefits [3]. This method was based on the assumption that a combined $35 \%$ of the production of steel and aluminum from semimanufactured goods was transferred to other uses [4]. Although the socio-economic indicators are also declining, the expert's analysis shows that this is mainly due to changes in the way we travel-i.e., increased occupancy, utilization, and delivery of machinery across industries [5]. Finally, due to the low availability of scrap, we see a moderate reduction in environmental factors in the implementation of scrap disposal. For example, while steel and aluminum waste can be reversed by $90 \%$ in the construction sector [6], scrap available for this use is only $7 \%$, for example, in the manufacturing sector [6]. This leads us to believe that, although this intervention may be good practice and beneficial to manufacturing companies, its benefits may be limited on a global scale [1].

\section{Thailand}

The domestic demand for steel in Thailand is projected to increase by $1-4 \%$ annually to around 17.0-19.0 million tons between 2019 and 2021 [7]. This positive outlook will be maintained by increasing demand from the manufacturing sector as well as related consumer industries such as cars and machinery [7]. The private sector, however, held back investments until the political outlook became clearer following the 2019 national elections, which led to poorer business conditions in the year, but it was predicted that the situation would improve again in 2021 [8]. Although the world economy faces a new "COVID-19" pandemic and the steel industry is therefore adversely affected, the change in the situation in 2021 is estimated to be positive.

Used as an outlet for steel production, countries that do not have a domestic source of highquality iron ore use scrap and ore are different processes [9]. In the case of the steel mill with melting facilities in Thailand, there are fewer domestic upstream steelworks, a steel manufacturer's industrial plants due to a combination of concerns about potential environmental and health impacts in nearby communities, as well as high investment costs, which make it even more difficult to break down [10]. However, most Thai manufacturers usually produce long-term products made from their own steel production from scrap metal to rolled products (Melt Shop), and also alloys are used as inputs. This helps to reduce the cost of raw materials, which is $47.1 \%$ of all costs to those furnace-equipped manufacturers. Instead, those without a furnace need to buy their raw material [11] and this results in significantly higher raw material costs (Table 1).

Table 1 Top 5 countries that have imported and exported in Thailand in 2018

\begin{tabular}{lll}
\hline No. & $\begin{array}{l}\text { Imported } \\
\text { Scrap, iron ore, and ingot }\end{array}$ & $\begin{array}{l}\text { Exported } \\
\text { Scrap, iron ore, and ingot }\end{array}$ \\
\hline 1 & USA (23\%) & Philippines $(21 \%)$ \\
2 & Russian (10\%) & India (19\%) \\
3 & Myanmar (8\%) & Indonesia (12\%) \\
4 & India (8\%) & Bangladesh (10\%) \\
5 & China (3\%) & Korea (10\%) \\
\hline
\end{tabular}

Source: Mahattanalai [12] 
Production costs increased in 2018 (66\% share of total production costs) and the prices of scrap metal and imported raw material inputs increased. Most Thai steel mills use scrap metal as their main source of steel (Table 2).

\section{Precautions for Scrap Users in Southeast Asia in 2021}

In Southeast Asia, scrap customers are watching some changes with a certain amount of trepidation. Chinese scrap needs are expected to boost local prices and reduce the output of these consumers [13]. Countries may impose a ban on scrap exports or restrictions in order to protect domestic availability or to raise cap prices. At the end of the day, rebar prices and billet prices are likely to rise if scrap prices rise. China's excess production would struggle to find a global home, because many countries, such as Vietnam, do not allow rebar imports [14]. China imported iron ore from a wide range of sources in Q2 and Q3 in 2020 as if it helped to restrict supplies - or to retaliate for political discourse with Australia [15]. Increasing imports of scrap could ease the demand for iron ore. Analysts expect iron ore prices to remain high for the rest of the years 2020 and 2021 [16].

\section{Current CE Practices in Thailand}

The local government shall be the primary authority responsible for managing municipal solid waste (collection, transport, and disposal), including all electrical waste within its administrative area. There is nothing in place to regulate the generation of steel shredding processes and to handle the entire waste stream of steel shredding. Pre-consumer steel shredding products are not the responsibility of producers and importers. As a result, scrap steel shredding is often thrown away and mixed with household waste and is finally disposed of $[17,18]$. Approximately $57 \%$ of local waste collection and disposal organizations have spent only 7.88 million tons, i.e., air pollution control incinerators or built waste disposal facilities, or $53 \%$ of the total amount of waste collected [19]. A total of 466 waste sites operated by the public and private sectors have been transferred to waste disposal sites. On the other hand, approximately $47 \%$ of the total waste collected, or 6.93 million tons, has been disposed of by open dumping. For the remaining $43 \%$ of local authorities that do not provide waste services, 6.53 million tons of waste have been disposed of annually, or 13.5 million tons of waste illegally disposed of each year [20]. Moreover, there is a lack of rules for managing waste generation and long-standing planning and collaborative planning among stakeholders in the upstream waste management process [21].

The national waste management objective was stated in the Environment and Pollution Control Plan 2012-2016 ([22], p. 369). The level of environmental and waste disposal is the only two metrics used as national planning tools, the objective of which is as follows:

Table 2 Thailand scrap price

\begin{tabular}{lllll}
\hline Domestic scrap price & & & & \\
\hline & 2015 & 2016 & 2017 & 2018 \\
\hline Price (THB/ton) & 7,934 & 7,825 & 10,304 & 12,204 \\
Growth (\% YoY) & -29.6 & -1.4 & 31.7 & 18.4 \\
\hline
\end{tabular}

Source: Mahattanalai [12] 
- Safe disposal — not less than $50 \%$ of the total waste generated.

- Waste utilization level - not less than $30 \%$ of the total waste generated should be generated.

The study of waste management practices and policies shows that traditional patterns of consumption and production are not accompanied by constructive and creative measures. Business, as usual, is no longer the way to manage waste and resources efficiently; it needs policy and upstream management and behavioral change.

\section{Circular Economy}

According to the Ellen Macarthur Foundations, circular economy (CE) was probably first identified and conceptualized as "a conscious and designedly restorative or regenerative industrial system" [23]. This means exploring and creating opportunities for a change in cradle-to-cradle from the use of renewable energy, from the use of toxic chemicals to their disposal and from waste to waste through the superior design of materials, goods, systems, and business models [24]. The circular economy is becoming a new vision for resource management, energy, value creation, and entrepreneurship. It is also explained that several business models may be needed to maximize their usefulness and overlap at different stages of the product or asset life cycle. Linder \& Williander [25] defines a circular business model as the "business model in which the conceptual principle of value creation is based on the use of economical values retained in products following use in new products' production." Mentink [26] describes the CE as "an economic system with shut down material loops" and the CE "as a justification for creating, providing, and capturing value within and with a shutdown material loop."

\section{Methodology}

The study sample consisted of 67 managers from Thai steel companies, consisting of top managers. This sample objective is chosen as the output of the circular economy is routinely considered by the top managers in the business. The interview was conducted between December 2020 and January 2021.

\section{Interview Questions}

1. How are scrap yards and manufacturers equipped to properly change their business to zero waste, $\mathrm{CE}$, and shredder plans?

2. What is needed (financial, funds, legislation, rewards, tax considerations, partnership, process management, forum, etc.)?

3. What are their capabilities in terms of (equipment, services, resources, etc.) adapting their plant to the CE and shredding themes?

4. What would their return be if they were to adopt the CE technique and set up a shredder plant?

\section{Result}

Of the 67 interviewees, $80 \%$ strongly insisted on establishing long-term relationships with our suppliers is an important achievement. Sixty-two percent of the interviewees have strongly indicated that their 
quality and efficiency of delivery bring back lean production. Seventy percent of the companies received ISO certification for the system. Half of the respondents find it difficult to sort scrap metal for recycling. Thirty-three percent believe that their company's financial capacity to manage scrap is sufficient. $22 \%$ believe that their company's financial ability to manage scrap is not sufficient. $94 \%$ are willing to develop some cost-reduction strategies. $94 \%$ believe that a circular economy is a worthwhile practice. $86.8 \%$ care that they are very concerned about the environment. They have long-term environmental concerns in $88.2 \%$ of cases. $95.6 \%$ of the interviewees believe that the circular economy provides the steel industry with business opportunities. $92.6 \%$ believe that the circular economy gives their company the opportunity to participate in facilitating the production of recycled steel products. $87 \%$ said that their environmental success was appreciated by the media (awards and public relations). $79.4 \%$ of the total stated that they wanted the government to obtain an award for successful environmental results.

Moreover, 75\% argued that fines could be levied for non-compliance with the recycling rule. $91.1 \%$ agree that the government should have funds in line with the recycling regulations. $73.6 \%$ accepted that industrial steel consumers would be able to pay a higher price for clean goods. $91 \%$ said that governments should have grants and tax benefits to implement the circular economy. $70.6 \%$ claimed that their company offered seminars and activities to community education specialists. $80.1 \%$ argued that they had to provide sustainability preparations to the organization's representatives so that workers and administrators could acquire the expertise and information needed for a circular economy.

Furthermore, $64.7 \%$ state that there is no federal money to recover scrap metal. $32.3 \%$ claimed that there was a shortage of workers with experience in scrap metal separation. $80.6 \%$ suggested that government departments or organizations should meet on the prospect of collecting funds. $89.5 \%$ agree that government departments or institutions must provide input on a daily basis to stakeholders in order to meet their environmental objectives. $89.5 \%$ argued that the adjustment of professional ties between stakeholders was a must. $89.6 \%$ argued that the reduction of pollution could be achieved by the re-use of cleaner total manufacturing

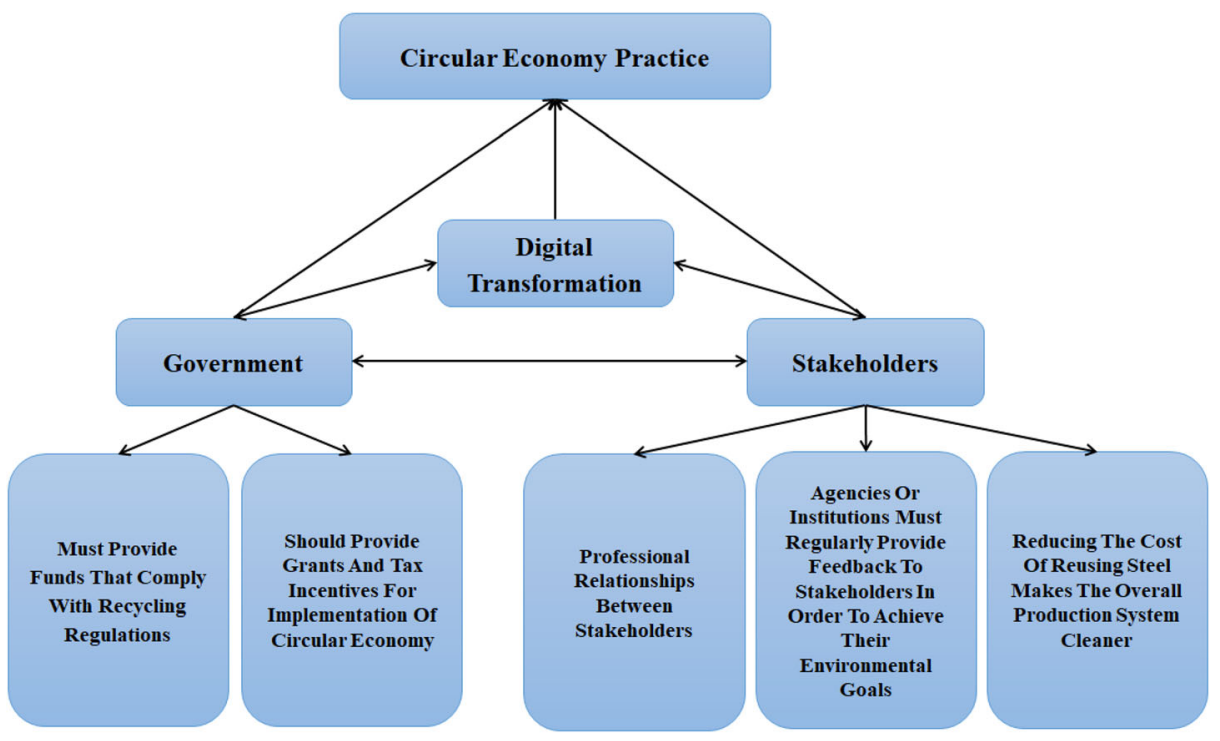

Fig. 1 Circular economy practice model. Source: authors 
processes. 93.9\% claimed that a reduction in the cost of reusing steel made the overall manufacturing environment healthier. $89.6 \%$ assumed that consumer loyalty ratings for green goods would improve. $91.1 \%$ discovered that the use of green packaging (using environmentally sustainable products, re-use of reverse logistics experience, taking into account weight reduction etc.) is successful. $88.1 \%$ felt that the government should amend the laws on steel imports and exports. $84.8 \%$ state globalization has made the local small-scale steel industry more complicated. $89.6 \%$ argued that compliance with the circular economy principles would improve the efficacy of the commodity. And $95.5 \%$ said that there should be a web portal to promote trade and eradicate scrap.

In conclusion, we inferred the model in Fig. 1 from the interviewee's statements.

\section{Declarations}

Conflict of interest We declare there is no conflict of interest.

\section{References}

1. Donati F, Aguilar-Hernandez GA, Sigüenza-Sánchez CP, de Koning A, Rodrigues JF, Tukker A (2020) Modeling the circular economy in environmentally extended input-output tables: methods, software and case study. Resour Conserv Recycl 152:104508

2. Schwab K (2017). The fourth industrial revolution. Currency.

3. van Eijck J, Romijn H, Balkema A, Faaij A (2014) Global experience with Jatropha cultivation for bioenergy: an assessment of socio-economic and environmental aspects. Renew Sust Energ Rev 32:869889

4. Tsai WH, Lan SH, Huang CT (2019) Activity-based standard costing product-mix decision in the future digital era: green recycling steel-scrap material for steel industry. Sustainability 11(3):899

5. Maloutas T (2015). Socio-economic segregation in Athens at the beginning of the twenty-first century. Socio-Economic Segregation in European Capital Cities: East Meets West. Routledge, Milton Park, 156185

6. Allwood JM, Cullen J M (2015). Sustainable materials without the hot air: making buildings, vehicles and products efficiently and with less new material. UIT Cambridge Limited.

7. Zh-cn.facebook.com. 2020. Krungsri Research. [online] Available at: <https://zh-cn.facebook.com/ 840301786162370/posts/thailand-industry-outlook-2019-21-steel-industry-from-2019-to-2021-domesticdema/1152649744927571/> [Accessed 13 August 2020]

8. Apisitniran L, 2020. Steel Producers brace for demand dip. [online] https://www.bangkokpost.com. Available at: <https://www.bangkokpost.com/business/1877804/steel-producers-brace-for-demand-dip> [Accessed 10 August 2020]

9. Liang X, Lin Q, Jiang M, Ascui F, Lu D, Muslemani H et al (2020) Lower carbon technology approaches for steel manufacturing in China. Appl Energy

10. Somboonwiwat T, Khompatraporn C, Miengarrom T, Lerdluechachai K (2018) A bi-objective environmental-economic optimisation of hot-rolled steel coils supply chain: a case study in Thailand. Advances in Production Engineering \& Management 13(1):93-106

11. Toomwongsa N, 2017. Thailand industry outlook 2017-19, steel industry. [online] Krungsri.com. Available at: <https://www.krungsri.com/bank/getmedia/ada4bb8a-ffdd-4a1b-a3f5-2877a15b05d5/IO_Steel Industry_2017_EN.aspx> [Accessed 10 August 2020]

12. Mahattanalai T, 2019. Steel industry. [online] Krungsri.com. Available at: <https://www.krungsri.com/ bank/getmedia/59ea1063-b869-46ff-9fbf-ce3da6848834/IO_Steel_190827_EN_EX.aspx> [Accessed 10 August 2020].

13. Fan Y, Fang C (2020) Circular economy development in China-current situation, evaluation and policy implications. Environ Impact Assess Rev 84:106441

14. Cisa pushes tax changes to boost China steel scrap use. (2021). Retrieved 24 February 2021, from https:// www.argusmedia.com/en/news/2183369-cisa-pushes-tax-changes-to-boost-china-steel-scrap-use? backToResults $=$ true 
15. Wang ZX, Zhao YF, He LY (2020) Forecasting the monthly iron ore import of China using a model combining empirical mode decomposition, non-linear autoregressive neural network, and autoregressive integrated moving average. Appl Soft Comput 94:106475

16. Egbaria F, Gobitz M, Burns S (2020). Ferrous metals archives - steel, aluminum, copper, stainless, rare earth, metal prices, forecasting | MetalMiner. Retrieved 19 August 2020, from https://agmetalminer.com/ category/ferrous-metals/

17. Ghosh, S K (Ed. P.368). (2020a). Circular economy: global perspective. Springer Singapore.

18. Sakolnakorn TPN, Kroeksakul P, Kaewbutdee P, Naipinit A, Laeheem K (2016) Land-use change under the management of the agricultural land reform office: a case study in Phuket. NIDA Development Journal $56(4)$

19. https://www.unescap.org/sites/default/files/Closing\%20The\%20Loop_Sai\%20Mai\%20District\%2C\% 20Bangkok\%20Case\%20Study.pdf

20. https://en.wikipedia.org/wiki/Waste_management_in_Thailand

21. Tangwanichagapong S, Logan M, Visvanathan C (2020) Circular economy for sustainable resource management: the case of packaging waste sector in Thailand, In Circular Economy: Global Perspective (pp. 353-387). Springer, Singapore

22. Ghosh, S K (Ed. P.369) (2020b). Circular economy: global perspective. Springer Singapore.

23. Lewandowski M (2016) Designing the business models for circular economy-towards the conceptual framework. Sustainability 8(1):43

24. Cháveza CAG, Romerob D, Rossic M, Lugliettic R, Johanssona B (2019) Circular lean product-service systems design: a literature review, framework proposal and case studies. Procedia CIRP 83:419-424

25. Linder M, Williander M (2017) Circular business model innovation: inherent uncertainties. Bus Strateg Environ 26(2):182-196

26. Mentink BAS (2014). Circular business model innovation: a process framework and a tool for business model innovation in a circular economy. 